\title{
Assembly of Molten Transition Metal Salt-Surfactant in a Confined Space for the Synthesis of Mesoporous Metal Oxide-Rich Metal Oxide-Silica Thin Films
}

\author{
Cüneyt Karakaya, Yurdanur Türker, Cemal Albayrak, and Ömer Dag* \\ Department of Chemistry, Bilkent University, 06800 Ankara, Turkey \\ Supporting Information
}

\begin{abstract}
Uniform and homogeneous coating of mesoporous materials with an active (catalytically, photonic, electrical) nanostructure can be very useful for a number of applications. Understanding chemical reactions in a confined space is important in order to design new advanced materials. In this work, we demonstrate that an extensive amount (as high as $53 \mathrm{~mol}$ percent) of transition metal salts can be confined between silica walls and two surfactant domains (cetyltrimethylammonium bromide, CTAB, and lauryl ether, $\mathrm{C}_{12} \mathrm{H}_{25}\left(\mathrm{OCH}_{2} \mathrm{CH}_{2}\right)_{10} \mathrm{OH}$, $\left.\mathrm{C}_{12} \mathrm{EO}_{10}\right)$ as molten salts and then converted into sponge-like mesoporous silica-metal oxides by thermal annealing. This

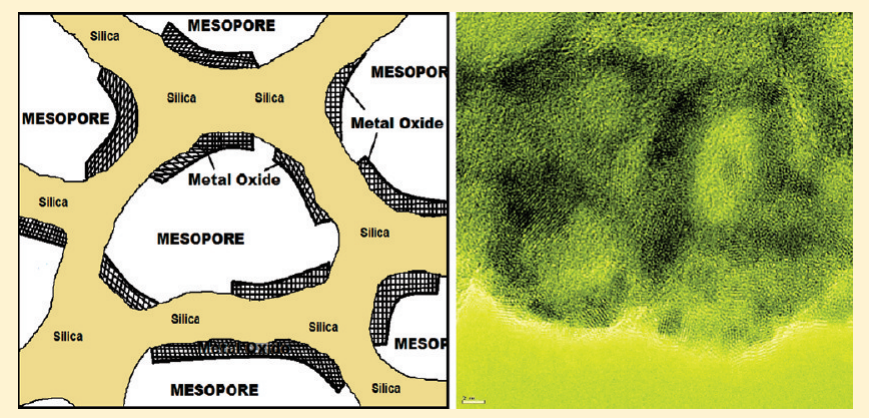
investigation has been carried out using two different salts, namely, zinc nitrate hexahydrate, $\left[\mathrm{Zn}\left(\mathrm{H}_{2} \mathrm{O}\right)_{6}\right]\left(\mathrm{NO}_{3}\right)_{2}$, and cadmium nitrate tetrahydrate, $\left[\mathrm{Cd}\left(\mathrm{H}_{2} \mathrm{O}\right)_{4}\right]\left(\mathrm{NO}_{3}\right)_{2}$, in a broad range of salt concentrations. The $\mathrm{ZnO}$ (or $\mathrm{CdO}$ ) layers are as thin as about $\sim 1.6 \mathrm{~nm}$ and are homogenously coated as crystalline nano-islands over the silica pore walls.
\end{abstract}

KEYWORDS: mesoporous materials, metal oxides, thin films, molten phase, lyotropic liquid crystals, confinement effect

\section{INTRODUCTION}

The liquid crystalline templating (LCT) ${ }^{1}$ and evaporationinduced self-assembly (EISA) ${ }^{2}$ processes have opened a new era for designing new materials in the form of mesostructured mesoporous thin films. ${ }^{1-8}$ The surface modification of mesoporous materials with metal oxides, sulfides, and selenides is needed to create advanced applications. In the existing literature, metal ions are usually incorporated into the pores by impregnation and then converted to their oxides, sulfides, selenides, and metals. ${ }^{9-15}$ Salt-water-surfactant lyotropic liquid crystalline (LLC) mesophases have also been adopted to incorporate salt species into the meso-channels of the mesostructured films and monoliths. ${ }^{16-18}$ However, all these methods produced metal oxide nanoparticles with a size of a few nanometers in the mesoporous silica in relatively low amounts. Unfortunately, no methods are available to coat the internal surface of mesoporous materials with materials less than $2.0 \mathrm{~nm}$. Recently, Wang et al. ${ }^{19}$ have introduced a solid-state grinding method to incorporate salt species into the as-prepared mesostructured silica powder that can be converted into homogeneously coated mesoporous silica-metal oxide upon calcination. ${ }^{19-24}$ In the as-prepared samples, it is likely that the salt species are confined in the molten phase between the silica walls and surfactant aggregates. Using this approach, the metal oxide to silica ratio has been improved to $35 \mathrm{w} / \mathrm{w} \%$. However, above $35 \mathrm{w} / \mathrm{w} \%$, this method also fails and produces larger metal oxide particles outside of the pores. Maximum loading only ensures about $15 \%$ of the silica walls are being coated with metal oxide with a thickness of less than $2.0 \mathrm{~nm}$. Over all, these methods use multiple steps and preprepared mesoporous silica powders and are not applicable to thin films.

Recently, we have introduced that two surfactants (a charged surfactant, such as CTAB or SDS, and a nonionic surfactant, such as $\mathrm{C}_{n} \mathrm{H}_{2 n+1}\left(\mathrm{OCH}_{2} \mathrm{CH}_{2}\right)_{m} \mathrm{OH}$, represented as $\left.\mathrm{C}_{n} \mathrm{EO}^{m}\right)$ and an extensive amount of zinc nitrate hexahydrate $(\mathrm{ZnX})$ can be mixed to form LLC mesophases. ${ }^{25,26}$ We have also found that the salt species are in the molten phase in the salt-surfactant LLC mesophases. ${ }^{27}$ Note also that most metal nitrates have very low melting points. For instance, the melting points of $\mathrm{ZnX}$ and cadmium nitrate tetrahydrate (CdY) salts are as low as 36.4 and $56^{\circ} \mathrm{C}$, respectively. The melting point of $\mathrm{ZnX}$ scales as a function of $1 / \mathrm{d}(\Delta T=116 / d$, where $\Delta T$ is the melting point change from the bulk $\mathrm{ZnX}, d$ is the diameter of the space in nanometers, and 116 is a constant) in a confined space. ${ }^{28}$ This means that if one puts $\mathrm{ZnX}$ in a $3.0 \mathrm{~nm}$ pore (typical in mesoporous materials), its melting point decreases to $-2.3{ }^{\circ} \mathrm{C}$. Confining salt species in the mesostructure decreases the melting point of the salt and keeps the salt species in the liquid phase. This concept has been used to determine the pore size of nanoporous materials by filling the pores with molten zinc nitrate salt ${ }^{28}$ and to design salt-surfactant liquid crystalline mesophases. ${ }^{26,27,29-32}$

Received: February 16, 2011

Published: May 24, 2011 

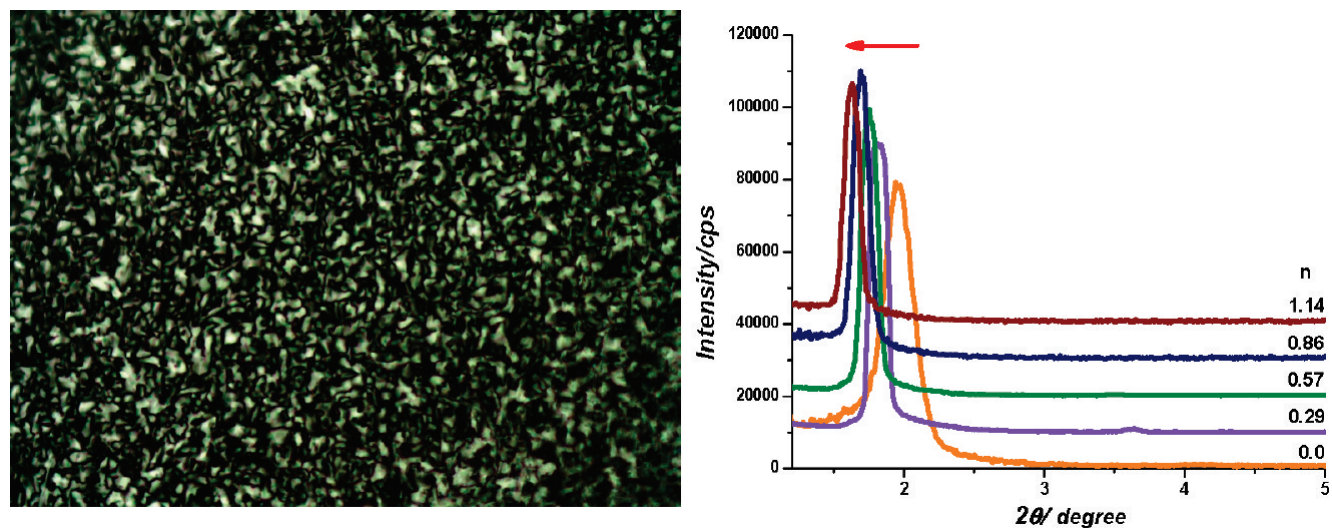

Figure 1. POM image of as-synthesized meso- $\mathrm{SiO}_{2}-\mathrm{ZnX}-1.14$ thin film (left) and XRD patterns of the as synthesized $m e s o-\mathrm{SiO}_{2}-\mathrm{ZnX}-n$ thin films $(n$ is shown on the patterns).

In this contribution, the salt-surfactants LLC mesophase has been employed for the first time to encapsulate as high as 60 or $71 \mathrm{w} / \mathrm{w} \%$ salt species ( $\mathrm{ZnX}$ or $\mathrm{CdX}$, respectively) between the silica walls and surfactant domains in the channels of mesostructured silica that can be calcined to form uniformly coated mesoporous zinc oxide-silica or cadmium oxide-silica thin films.

\section{EXPERIMENTAL SECTION}

2.1. Sample Preparation. A mixture of a desired amount of $\mathrm{ZnX}\left(\left[\mathrm{Zn}\left(\mathrm{H}_{2} \mathrm{O}\right)_{6}\right]\left(\mathrm{NO}_{3}\right)_{2}\right)$ or $\mathrm{CdY}\left(\left[\mathrm{Cd}\left(\mathrm{H}_{2} \mathrm{O}\right)_{6}\right]\left(\mathrm{NO}_{3}\right)_{2}\right)$, $0.291 \mathrm{~g} \mathrm{CTAB}, 0.500 \mathrm{~g} \mathrm{C}_{12} \mathrm{EO}_{10}$, and $4.500 \mathrm{~g}$ deionized water was vigorously stirred for 1 day to get a clear solution. Then $0.050 \mathrm{~g}$ of concentrated $\mathrm{HNO}_{3}$ was added to the above solution and stirred for another $5 \mathrm{~min}$. Finally, $0.850 \mathrm{~g}$ TMOS was added to the mixture and stirred for an additional $5 \mathrm{~min}$. Note that the solution must be homogeneous and clear before spin coating over any substrate. A few drops of the above solution was put on a substrate over the spin coater and spanned for $1 \mathrm{~min}$ at 1200 or $3500 \mathrm{rpm}$ (for the TEM imaging). Immediately after spin coating the films, the $\mathrm{ZnX}$ and $\mathrm{CdY}$ film samples were put into an oven for aging at 55 and $65^{\circ} \mathrm{C}$, respectively, or calcined starting from those temperatures to $450{ }^{\circ} \mathrm{C}$ using a temperature controlled oven by $1{ }^{\circ} \mathrm{C} / \mathrm{min}$ increments. In a sample of meso- $\mathrm{SiO}_{2}-\mathrm{ZnX}$ 1.14, the amounts of $\mathrm{ZnX}, \mathrm{CTAB}, \mathrm{C}_{12} \mathrm{EO}_{10}, \mathrm{H}_{2} \mathrm{O}, \mathrm{HNO}_{3}$, and TMOS are 1.900, 0.291, 0.500, 4.500, 0.050, and $0.850 \mathrm{~g}$, respectively. The calcined sample was labeled as meso- $\mathrm{SiO}_{2}-\mathrm{ZnO}-1.14$.

2.2. Synthesis of meso-SiO calcined meso- $\mathrm{SiO}_{2}-\mathrm{CdO}-n$ thin films into a vacuum chamber and evacuate the chamber for $2 \mathrm{~min}$. Expose the meso- $\mathrm{SiO}_{2}-$ CdO- $n$ samples to 300 Torr $\mathrm{H}_{2} \mathrm{~S}(\mathrm{~g})$ until complete reaction (about $100 \mathrm{~min}$ ) to obtain meso-SiO $2-\mathrm{CdS}-n$ thin films. Then, pump out the unreacted excess $\mathrm{H}_{2} \mathrm{~S}$ gas from the reaction media for $5 \mathrm{~min}$ before removing the sample from the reaction chamber.

2.2. Characterization. The FTIR spectra were recorded using a Bruker Tensor 27 model FTIR spectrometer. A Digi Tect TM DLATGS detector was used with a resolution of $4.0 \mathrm{~cm}^{-1}$ in the $400-4000 \mathrm{~cm}^{-1}$ range. The spectra were recorded using the samples coated on silicon wafers or using dry $\mathrm{KBr}$ pellets. The UV-vis absorption spectra were recorded using thin films coated over quartz substrates and a Thermo Scientific Evolution 300/600 UV-visible spectrometer. The XRD patterns were recorded on a Rigaku Miniflex and Pananalytical multipurpose $\mathrm{X}$-ray diffractometer using a high power $\mathrm{Cu} \mathrm{K} \alpha$ source operating at $30 \mathrm{kV} / 15 \mathrm{~mA}$ and $45 \mathrm{kV} / 40 \mathrm{~mA}$, respectively. The POM images were obtained in transmittance mode on a ZEISS Axio Scope A1 polarizing optical microscope. The SEM images were recorded using a Hitachi HD-2000 STEM in SEM mode, and the EDS data was collected using a ZEISS EVO-40 SEM operated at $15 \mathrm{kV}$ with a Bruker AXS XFlash detector 4010 attached to the same microscope. The high resolution transmittance electron microscope (HRTEM) images were recorded on a FEI Technai G2 F30 at an operating voltage of $200 \mathrm{kV}$. The calcined film samples were scribed and ground in a mortar with $5 \mathrm{~mL}$ of acetone and dispersed using sonication for $5 \mathrm{~min}$. One drop of the dispersed acetone solution was put on a TEM grid and dried over a hot plate. The $\mathrm{N}_{2}(77.4 \mathrm{~K})$ sorption measurements were performed with a TriStar 3000 automated gas adsorption analyzer (Micrometrics) in a relative pressure range, $P / P_{0}$, from 0.01 to 0.99 . To provide high accuracy and precision in the determination of $P / P_{0}$, the saturation pressure $\mathrm{P}_{0}$ was measured over 120 min intervals. The powder samples, which were obtained by scraping about 20 glass slides of each film sample were dehydrated under $\left(\sim 10^{-2}\right.$ Torr $)$ vacuum for $3 \mathrm{~h}$ at $300{ }^{\circ} \mathrm{C}$ before measuring in order to remove adsorbed water and volatile species in the pores.

\section{RESULTS AND DISCUSSION}

The film samples were prepared by spin coating a clear solution of $\mathrm{CTAB}, \mathrm{C}_{12} \mathrm{EO}_{10}, \mathrm{ZnX}$ (or $\mathrm{CdY}$ ), $\mathrm{HNO}_{3}$, water, and TMOS. The content of the solutions has been optimized by changing the salt and $\mathrm{CTAB}$ concentrations. We found that the salt and $\mathrm{CTAB}$ concentrations, for stable samples, depend on each other (to incorporate a large amount of salt, one needs a high $\mathrm{CTAB}$ concentration). The film samples were prepared at $\mathrm{ZnX} / \mathrm{C}_{12} \mathrm{EO}_{10}$ mole ratios of 2.0, 4.0, 6.0, 8.0, 10.0, and 12.0, corresponding to a $\mathrm{ZnX} / \mathrm{SiO}_{2}$ mole ratio of $n$, where $n$ is 0.29 , $0.57,0.86,1.14,1.43$, and 1.71 , respectively, and represented as $m e s o-\mathrm{SiO}_{2}-\mathrm{ZnX}-n$. Notice that the minimum salt concentrations investigated in this work are the maximum concentrations in the current literature. ${ }^{19-24}$ The fresh film sample undergoes crystallization unless it is kept above 55 and $65^{\circ} \mathrm{C}$ for meso-SiO ${ }_{2}-\mathrm{ZnX}-n$ and $m e s o-\mathrm{SiO}_{2}-\mathrm{CdY}-n$, respectively. The initial temperatures were determined on the basis of the stability of the LLC phase of the mixture and the melting point of the salts. This step is followed by calcination using a temperature controlled oven from the pre-aged temperature to $450{ }^{\circ} \mathrm{C}$ with a $1{ }^{\circ} \mathrm{C} / \mathrm{min}$ intervals 

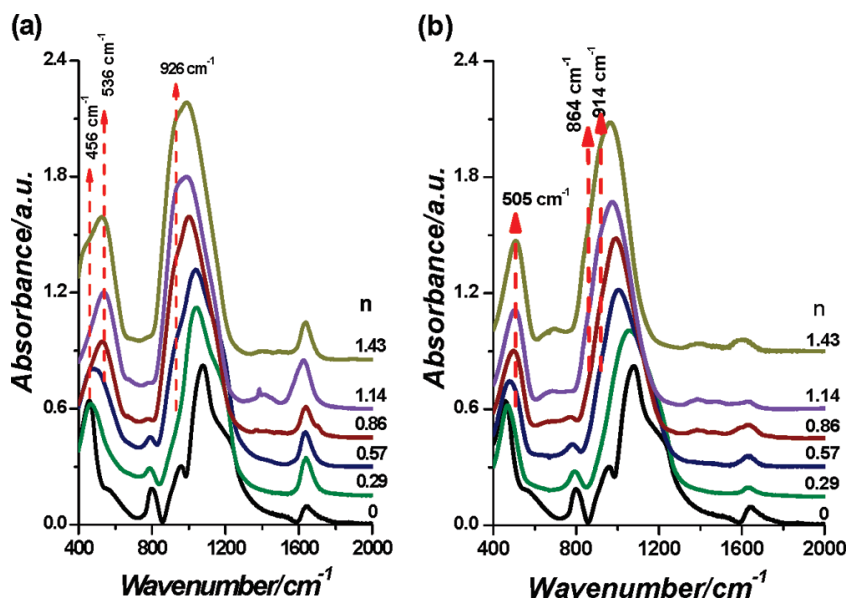

Figure 2. FTIR spectra of (a) meso- $\mathrm{SiO}_{2}-\mathrm{ZnO}-n$ and (b) meso$\mathrm{SiO}_{2}-\mathrm{CdO}-n$ ( $n$ is shown on the left on each spectrum).

(the resulting samples are represented as meso-SiO ${ }_{2}-\mathrm{ZnO}-n$ and meso- $\mathrm{SiO}_{2}-\mathrm{CdO}-n$, where $n$ is $0.29,0.57,0.86,1.14,1.43$, and 1.71). A typical synthesis solution for the meso- $\mathrm{SiO}_{2}-\mathrm{ZnX}-1.14$ sample contains $0.500 \mathrm{~g} \mathrm{C}_{12} \mathrm{EO}_{10}, 0.291 \mathrm{~g} \mathrm{CTAB}, 4.500 \mathrm{~g} \mathrm{H}_{2} \mathrm{O}$, $1.900 \mathrm{~g} \mathrm{ZnX}, 0.050 \mathrm{~g} \mathrm{HNO}_{3}$, and $0.850 \mathrm{~g} \mathrm{TMOS}$, which corresponds to mole ratios of 1.0, 1.0, 313, 8.0, 0.7, and 7.0, respectively.

The freshly prepared film samples are mesostructured soft and gel-like (likely liquid crystalline) at high salt concentrations and mesostructured rigid and solid at low salt concentrations. The fan-like texture under the polarized optical microscopy (POM) and the diffraction lines (100) and (200) are characteristic of oriented 2-D hexagonal mesostructures (Figure 1). The diffraction line(s) at small angles gradually shifts to higher angles with aging the as-prepared film samples (Figure 1). The aging step is very critical at all salt concentrations to keep the salt species in the hydrophilic domains or in the pores of the film samples. The fresh samples at high salt concentrations such as meso- $\mathrm{SiO}_{2}-$ $\mathrm{ZnX}-n$, where $n$ is $1.14,1.43$, and 1.71 , leach out most of the salt species in the first $5 \mathrm{~min}$ of the preparation. However, aging meso$\mathrm{SiO}_{2}-\mathrm{ZnX}-n$ samples at $45^{\circ} \mathrm{C}$ for $3 \mathrm{~h}$ stabilizes the salt species in the channels for several hours. To further elucidate the role of the aging step, we have also investigated the meso- $\mathrm{SiO}_{2}-\mathrm{ZnX}-1.14$ sample by aging at $45{ }^{\circ} \mathrm{C}$ for different periods of time and monitoring the leaching of the salt species using XRD and FTIR techniques. The fresh sample (meso-SiO $\left.{ }_{2}-\mathrm{ZnX}-1.14\right)$ diffracts strongly around $1.4^{\circ}, 2 \theta$ immediately after the preparation; however, within $5 \mathrm{~min}$, the diffraction line shifts to around $1.8^{\circ}, 2 \theta$ and loses its intensity and evolution of high angle diffraction lines (due to crystalline salt) as a result of leaching out of the salt species. Removal of the salt species from the hydrophilic domains of the mesophase shrinks the mesostructure more than $30 \%$.

Fortunately, aging the fresh meso-SiO $2-\mathrm{ZnX}-1.14$ at $45^{\circ} \mathrm{C}$ for $1,2,3,5,7,11$, and $24 \mathrm{~h}$ showed that the leaching process can be delayed and can go the longest if the sample is aged for $3 \mathrm{~h}$. It is very critical that one makes sure that the salt species do not crystallize before or during the calcination step to ensure no bulk $\mathrm{ZnO}$ or $\mathrm{CdO}$ formation. If the fresh film samples are calcined with a few minutes delay after the preparation, usually the salt species leach out and form an oxide layer on the outer surface of the silica films or submicrometer size bulk oxide crystallites.
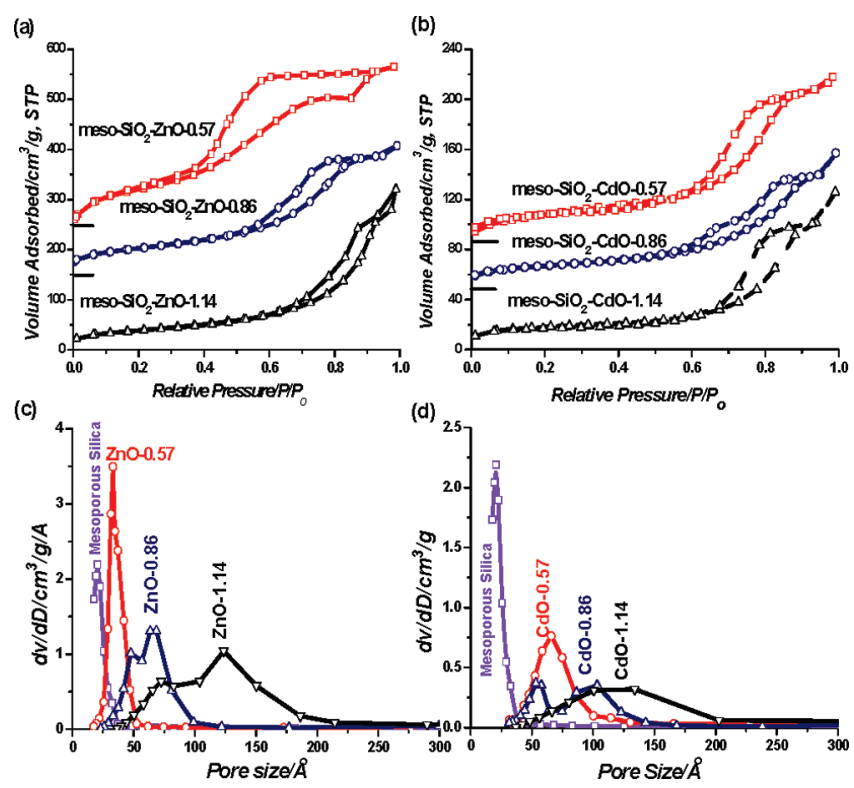

Figure 3. $\mathrm{N}_{2}$ sorption isortherms of (a) mesoporous- $\mathrm{SiO}_{2}-\mathrm{ZnO}-n$ samples and (b) mesoporous- $\mathrm{SiO}_{2}-\mathrm{CdO}-n$ samples and poresize distribution of (c) mesoporous- $\mathrm{SiO}_{2}-\mathrm{ZnO}-n$ and (d) mesoporous$\mathrm{SiO}_{2}-\mathrm{CdO}-n$ samples ( $n$ values are shown on each plot; onsets of the isotherms are shown with bars on the $y$-axis).

A slow calcination of the meso- $\mathrm{SiO}_{2}-\mathrm{ZnX}-n$ and meso- $\mathrm{SiO}_{2}-$ $\mathrm{CdY}-n$, starting at 55 and $65{ }^{\circ} \mathrm{C}\left(1{ }^{\circ} \mathrm{C} / \mathrm{min}\right.$ up to $\left.450{ }^{\circ} \mathrm{C}\right)$, respectively, immediately after spin coating produces transparent mesoporous films, represented as meso- $\mathrm{SiO}_{2}-\mathrm{ZnO}-n$ and meso$\mathrm{SiO}_{2}-\mathrm{CdO}-n$, respectively. Above a 10.0 salt $/ \mathrm{C}_{12} \mathrm{EO}_{10}$ mole ratio (corresponds to salt/silica mole ratio of 1.43 ), the film samples leach out some of the salt species and form bulk oxide. Fortunately, below an 8 salt $/ \mathrm{C}_{12} \mathrm{EO}_{10}$ mole ratio (about a salt/ silica mole ratio of 1.14), no bulk oxides have been observed over the thin film samples. Note also that the small angle diffraction line due to the mesostructure becomes very broad around $100-150{ }^{\circ} \mathrm{C}$ and lost around $250{ }^{\circ} \mathrm{C}$ during the calcination step, indicating a completely disordered mesoporosity that has been proven using $\mathrm{N}_{2}$ sorption measurements and TEM imaging (see later). For further insight on the structure of the nanoislands in the calcined films, we also recorded the wide angle XRD pattern of the samples that display broad features due to amorphous silica and extremely small oxide domains (Figure S1 of the Supporting Information.

The FTIR spectra of the meso-SiO $2-\mathrm{ZnX}-n$ and meso$\mathrm{SiO}_{2}-\mathrm{CdY}-n$ (where $n$ is $0.29,0.57,0.86,1.14$, and 1.43 ) samples display peaks between 1250 and $1500 \mathrm{~cm}^{-1}$ due to nitrate ion coordinated to $\mathrm{Zn}$ (II) or $\mathrm{Cd}$ (II) ion in the media; these peaks monotonically increase with increasing salt amounts in the samples (Figure S2 of the Supporting Information. At low salt concentrations, these peaks are better resolved, but at higher concentrations the spectra become similar to that of pure molten salt (Figure S2a,b of the Supporting Information). ${ }^{27}$ In this assembly process, the salt species are confined between the silica walls and ethylene oxide domains of the surfactants in the channel spaces of the mesostructured silica, likely in the molten phase. Otherwise, it is impossible to dissolve such a high concentration of salt in a solid matrix, such as mesostructured silica without crystallization of the salt species. Heating the meso$\mathrm{SiO}_{2}-\mathrm{ZnX}-1.14$ sample to $65^{\circ} \mathrm{C}$ enhances intensity of the peaks 
Scheme 1. Representation of Self-Assembly of Surfactants-Salt-Silica Species (liquid crystalline and soft matter; red domains are silica; stars are salt species, left) and meso-SiO $2-\mathrm{Mo}-n$ Thin Film (after calcination, right)
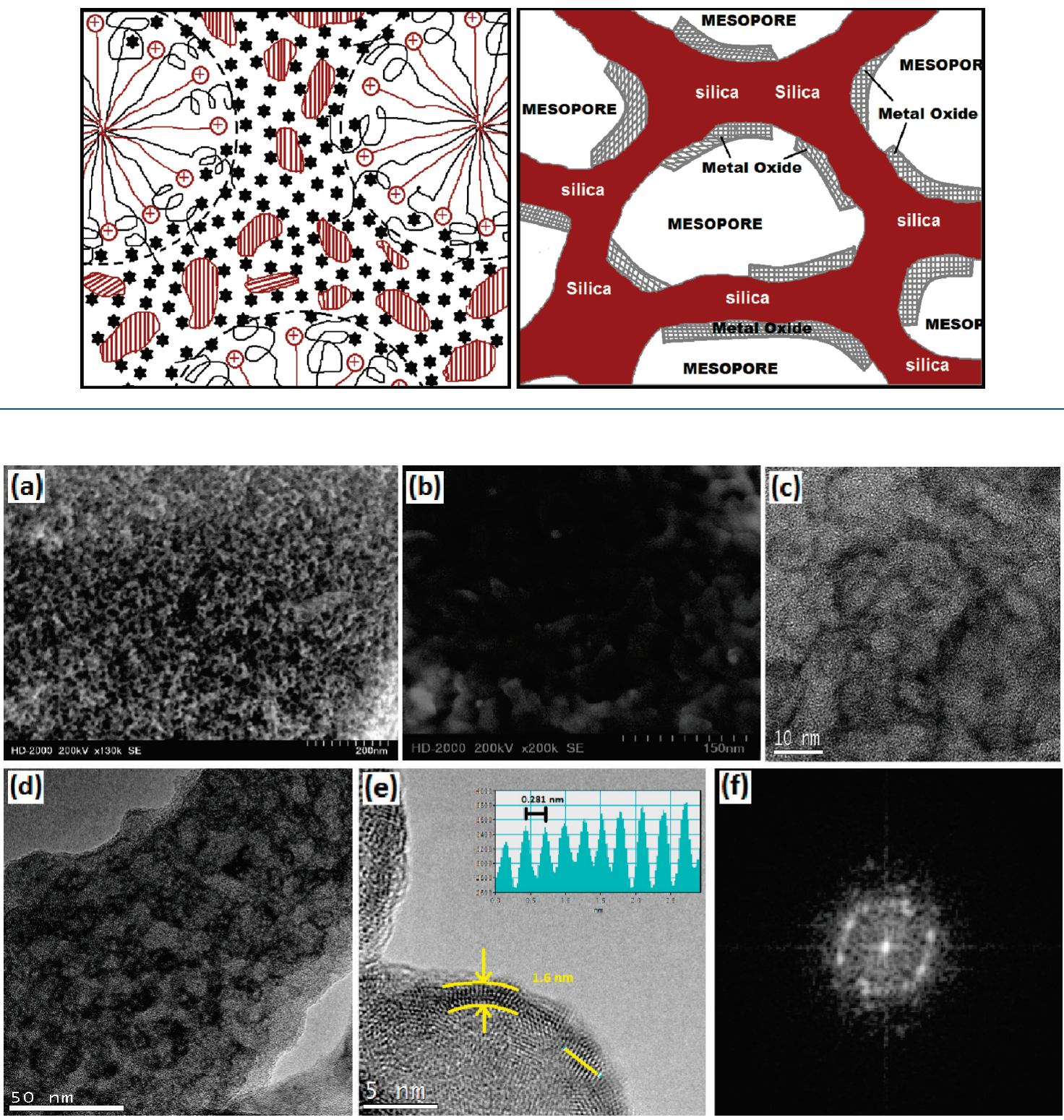

Figure 4. SEM images of meso- $\mathrm{SiO}_{2}-\mathrm{ZnO}-1.14$ (a, b). TEM images of meso-SiO${ }_{2}-\mathrm{ZnO}-n ; n$ is (c) 0.86, (d) 1.14 , and (e) 0.57 (inset is yellow line showing spacings between lines), and FFT of a crystalline domain (f).

at 1290 and $1460 \mathrm{~cm}^{-1}$ (Figure S2c of the Supporting Information). Clearly, the nitrate ions are coordinating to the metal ion by the evaporation of water molecules and stabilizing the ionic species by reducing the charge density of the media in the film samples. Note also that the nitrate peaks start to gradually lose their intensities upon further heating the film samples around $100{ }^{\circ} \mathrm{C}$ and completely disappear around $200^{\circ} \mathrm{C}$ (Figure S2 of the Supporting Information). Further heating of the samples results in mesoporous thin films, represented as meso-SiO $-\mathrm{MO}-n$ (where $\mathrm{M}$ is $\mathrm{Zn}$ or $\mathrm{Cd}$ and $n$ is the $\mathrm{MO} /$ silica mole ratio). Panels (a) and (b) of Figure 2 show a series of FTIR spectra recorded from the meso-SiO ${ }_{2}-\mathrm{ZnO}-n$ and meso-SiO ${ }_{2}-\mathrm{CdO}-n$ samples, respectively, upon calcination at $450{ }^{\circ} \mathrm{C}$. The peaks around $926 \mathrm{~cm}^{-1}$ in the meso- $\mathrm{SiO}_{2}-\mathrm{ZnO}-n$ samples and at 914 and $864 \mathrm{~cm}^{-1}$ in the meso- $\mathrm{SiO}_{2}-\mathrm{CdO}-n$ samples correspond to the $v$-SiO stretching mode $\mathrm{e}^{33,34}$ of the silica-metal oxide interface, $\mathrm{Si}-\mathrm{O}-\mathrm{Zn}$ and $\mathrm{Si}-\mathrm{O}-\mathrm{Cd}$, respectively. Further analysis of the FTIR spectra showed that the coating of the silica walls with zinc oxide starts as low as $100{ }^{\circ} \mathrm{C}$ from the $\mathrm{Si}-\mathrm{OH}$ side of the framework. The intensity of the peaks at 538 and $926 \mathrm{~cm}^{-1}$ in the spectra of meso- $\mathrm{SiO}_{2}-\mathrm{ZnO}-n$ gradually increase with increasing zinc oxide component of the samples up to a 1.14 metal oxide/silica mole ratio (Figure 2a). Above a $1.14 \mathrm{~mol}$ ratio, the pure silica peak at $456 \mathrm{~cm}^{-1}$ becomes visible in the spectra of meso- $\mathrm{SiO}_{2}-\mathrm{ZnO}-1.43$ (see top spectrum in Figure 2a) and meso-SiO $2-\mathrm{ZnO}-1.71$ (not shown) due to leaching and growth of the $\mathrm{ZnO}$ species in the samples. Similar changes occur in the meso- $\mathrm{SiO}_{2}-\mathrm{CdO}-n$ samples; the peaks at 505 and $914 \mathrm{~cm}^{-1}$ (due to $\mathrm{CdO}$ and $\mathrm{Si}-\mathrm{O}-\mathrm{Cd}$ stretching) gradually increase with increasing $\mathrm{CdO}$ concentration up to 0.86 
$\mathrm{Cd}$ (II) of the silicon mole ratio. Above $0.86 \mathrm{~mol}$ ratio, another peak at $864 \mathrm{~cm}^{-1}$ appears and increase in intensity occurs with further increasing the metal ion content of the sample (Figure 2b).
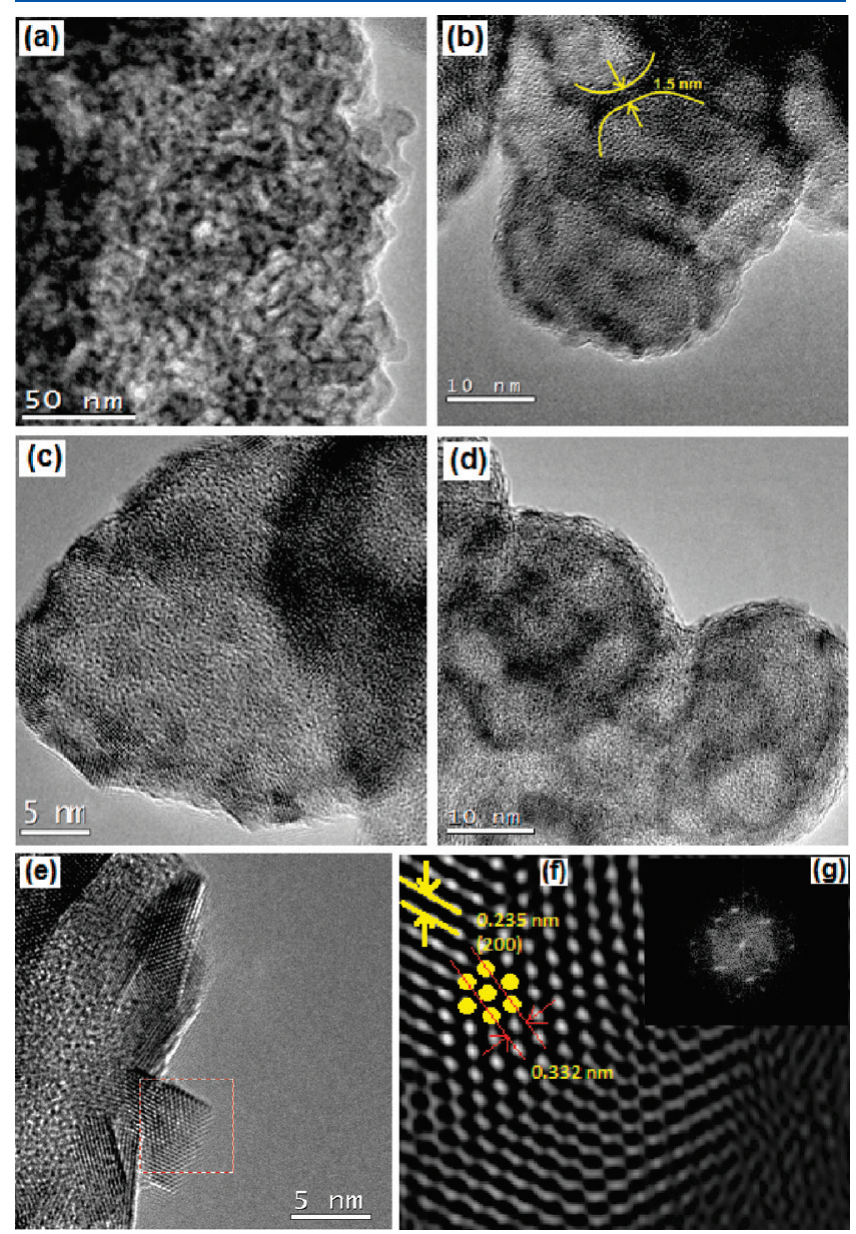

Figure 5. TEM images of the meso- $\mathrm{SiO}_{2}-\mathrm{CdO}-n ; n$ is (a,b) 0.57 , (c) 0.86 , and (d) 1.14. (e) HRTEM image of the meso- $\mathrm{SiO}_{2}-\mathrm{CdO}-0.86$ sample and the FT (f) and inverse FFT (g) of the marked region of panel (e).
Notice that even though there is also leaching of the excess CdY species in the meso- $\mathrm{SiO}_{2}-\mathrm{CdY}-n$ thin films, above a $1.14 \mathrm{~mol}$ ratio, the pure silica formation was not observed in the meso$\mathrm{SiO}_{2}-\mathrm{CdO}-n$ samples. This means that the silica-cadmium oxide interface is much stronger, and the cadmium ions are more reactive with the silica, in that there is no cleavage of the $\mathrm{Si}-\mathrm{O}-\mathrm{Cd}$ bonds. This observation is reasonable because the silica is an acid and $\mathrm{CdO}$ is a stronger base than $\mathrm{ZnO}$. The stronger interaction of $\mathrm{CdO}$ ensures better surface coverage compared to $\mathrm{ZnO}$, see latter. The FTIR spectrum of meso$\mathrm{SiO}_{2}-\mathrm{ZnO}-1.14$ also displays peaks at around $1300-1600 \mathrm{~cm}^{-1}$ region due to unburned organic impurities. The meso- $\mathrm{SiO}_{2}-\mathrm{ZnO}-$ 1.14 sample was further heated at 550,650 , and $750{ }^{\circ} \mathrm{C}$ to remove the unburned organic impurities and to check the stability of the samples at a higher temperature using FTIR spectroscopy (Figure S2d of the Supporting Information). The impurity peaks completely disappears at around $550^{\circ} \mathrm{C}$. However, the heating at $750^{\circ} \mathrm{C}$ causes separation of the silica and $\mathrm{ZnO}$; evolution of the peaks at 1100 and $456 \mathrm{~cm}^{-1}$ due to pure silica approves the separation of silica and $\mathrm{ZnO}$ species (Figure S2d of the Supporting Information).

The film samples were further analyzed using $\mathrm{N}_{2}$ adsorptiondesorption measurements using samples obtained from tens of glass slides, which were coated, calcined, and collected by scraping. Note also that it is extremely difficult to collect samples for the $\mathrm{N}_{2}$ sorption measurements from the meso- $\mathrm{SiO}_{2}-$ $\mathrm{ZnO}-0.29$ and meso-SiO${ }_{2}-\mathrm{CdO}-0.29$ samples. Therefore the $\mathrm{N}_{2}$ sorption measurements were limited to the meso-SiO $-\mathrm{MO}-n$ samples (where $\mathrm{M}$ is $\mathrm{Zn}(\mathrm{II})$ and $\mathrm{Cd}(\mathrm{II})$, and $n$ is $0.57,0.86$, and 1.14). All the $\mathrm{N}_{2}$ sorption data display type IV isotherms, characteristic of the mesoporous materials (Figure 3a,b). The BET surface areas are 430,175 , and $130 \mathrm{~m}^{2} / \mathrm{g}$ in the meso$\mathrm{SiO}_{2}-\mathrm{ZnO}-n$ samples and 85,55 , and $50 \mathrm{~m}^{2} / \mathrm{g}$ in the meso$\mathrm{SiO}_{2}-\mathrm{CdO}-n$ samples, where $n$ is $0.57,0.86$, and 1.14 , respectively. The surface area of the metal oxide free mesoporous silica is $950 \mathrm{~m}^{2} / \mathrm{g}$ with a relatively narrow pore size distribution centered at $2.1 \mathrm{~nm}$ (Figure $3 \mathrm{c}, \mathrm{d}$ ). However, the $\mathrm{BJH}$ pore size distribution curves of the metal oxide-containing samples become broader with increasing metal oxide content in the samples (Figure 3c,d). It increases from 3.4 to $12.4 \mathrm{~nm}$ in the meso$\mathrm{SiO}_{2}-\mathrm{ZnO}-n$ and 5.4 to $13.5 \mathrm{~nm}$ in the meso-SiO${ }_{2}-\mathrm{CdO}-n$
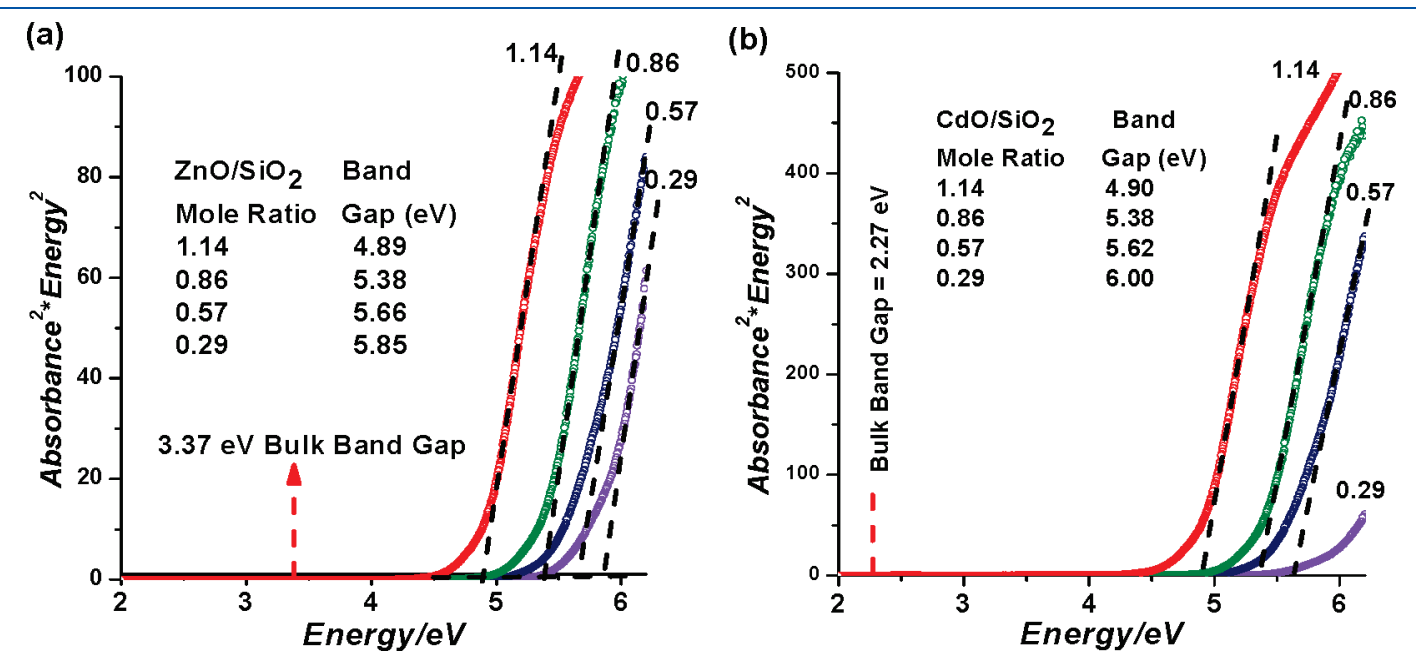

Figure 6. Direct gap fitting of UV-vis absorption spectra of (a) meso- $\mathrm{SiO}_{2}-\mathrm{ZnO}-n$ [ $n$ is the $\mathrm{ZnO} / \mathrm{SiO}_{2}$ mole ratio; inset is a table of composition $\left(\mathrm{ZnO} / \mathrm{SiO}_{2}\right.$ mole ratio) and band gap values $\left.(\mathrm{eV})\right]$ and $(\mathrm{b})$ meso- $\mathrm{SiO}_{2}-\mathrm{CdO}-n\left[n\right.$ is the $\mathrm{CdO} / \mathrm{SiO}_{2}$ mole ratio; inset is a table of composition $(\mathrm{CdO} /$ $\mathrm{SiO}_{2}$ mole ratio) and band gap values $\left.(\mathrm{eV})\right]$. 
Table 1. Parameter for Surface Loading Calculated from Measured Data ${ }^{a}$

\begin{tabular}{|c|c|c|c|c|}
\hline $\begin{array}{c}\text { meso- } \mathrm{SiO}_{2}-\mathrm{CdO}-n n \\
\left(\mathrm{CdO} / \mathrm{SiO}_{2} \text { mole ratio }\right)\end{array}$ & $\begin{array}{l}\text { surface area meso-SiO }{ }_{2}-\mathrm{CdO}-n \\
\qquad\left(\mathrm{~m}^{2} / \mathrm{g}\right)^{b}\end{array}$ & $\begin{array}{l}\text { surface area for } 1 \mathrm{~g} \text { of } \mathrm{CdO} \\
\qquad\left(\mathrm{m}^{2} / \mathrm{g}\right)^{c}\end{array}$ & $\begin{array}{c}\text { \% loading based on } \\
\text { TEM }^{d}\end{array}$ & $\begin{array}{c}\text { \% loading based on } \\
\text { UV-vis data }\end{array}$ \\
\hline 1.14 & 50 & 70 & 110 & 113 \\
\hline 0.86 & 55 & 85 & 90 & 101 \\
\hline 0.57 & 85 & 154 & 50 & 58 \\
\hline $\begin{array}{c}\text { meso }-\mathrm{SiO}_{2}-\mathrm{ZnO}-n n \\
\left(\mathrm{ZnO} / \mathrm{SiO}_{2} \text { mole ratio }\right)\end{array}$ & $\begin{array}{l}\text { surface area meso- } \mathrm{SiO}_{2}-\mathrm{ZnO}-n \\
\qquad\left(\mathrm{~m}^{2} / \mathrm{g}\right)^{b}\end{array}$ & $\begin{array}{l}\text { surface area for } 1 \mathrm{~g} \text { of } \mathrm{ZnO}^{c} \\
\qquad\left(\mathrm{~m}^{2} / \mathrm{g}\right)\end{array}$ & $\begin{array}{c}\text { \% loading based on } \\
\text { TEM }^{d}\end{array}$ & $\begin{array}{c}\text { \% loading based on } \\
\mathrm{UV}-\text { vis data }^{e}\end{array}$ \\
\hline 1.14 & 130 & 214 & 52 & 49 \\
\hline 0.86 & 175 & 325 & 34 & 37 \\
\hline 0.57 & 430 & 948 & 12 & 13 \\
\hline
\end{tabular}

${ }^{a}$ The samples that show more than $100 \%$ loading may contain some bulk CdO or it can be accepted within the accuracy range of BET measurement ( $10 \%$ is typical for the BET measurements). ${ }^{b}$ BET data. ${ }^{c}$ Calculated on the basis of BET data (for each gram of the metal oxide). ${ }^{d}$ Surface area of a flat $1 \mathrm{~g}$ and $1.6 \mathrm{~nm}$ thick metal oxide (TEM) on a substrate divide by the surface area measured (BET). ${ }^{e}$ Surface area of a flat $1 \mathrm{~g}$ thin metal oxide films (thickness was calculated from the UV-vis data) over a substrate divide by the surface area measured (BET).
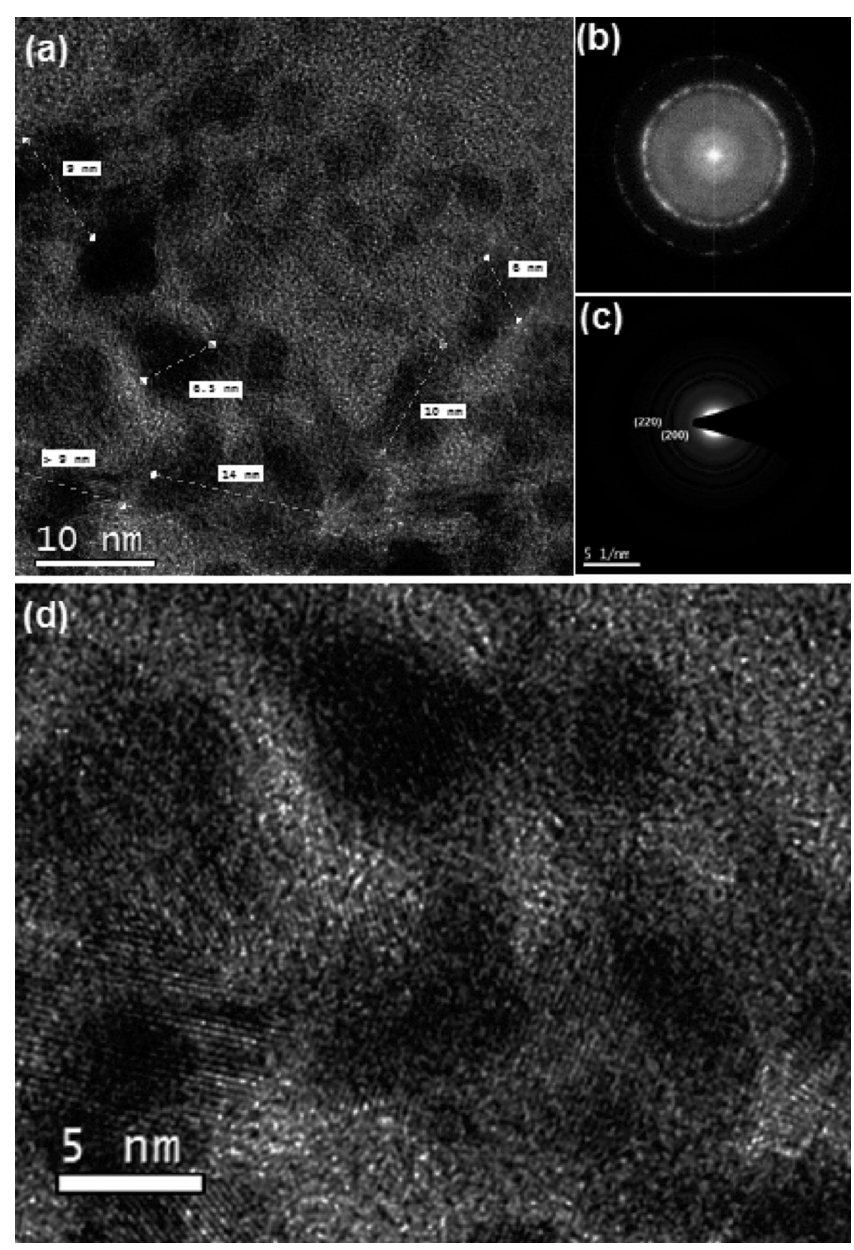

Figure 7. meso- $\mathrm{SiO}_{2}-\mathrm{CdO}-0.86$ film upon $\mathrm{HF}$ etching. (a) TEM image (b) FFT of a large area, (c) SAED pattern, and (d) magnified TEM image.

samples. The samples at high metal oxide concentrations display two pore systems, one with a relatively narrower and smaller pore size and another that is larger and broader. Clearly, the pore system changes in the presence of a large amount of metal oxide in the meso-SiO $-\mathrm{MO}-n$ films. The pore -walls are likely thicker than the pore walls in the pure silica (Scheme 1). The schema also summarizes the assembly and formation of the mesoporous silica-metal oxide thin films. Furthermore, a triangular H2-type hysteresis loop in the meso- $\mathrm{SiO}_{2}-\mathrm{ZnO}-0.57$ sample and a twostep desorption process for the meso- $\mathrm{SiO}_{2}-\mathrm{CdO}-0.86$ sample indicate pronounced pore blocking in the first case (ink-bottle type pores with small apertures, or plugs in the channels) and distribution of pore overture sizes in the second (possibly due to nonuniform distribution of the guests in the pores of the materials). These observations are consistent with increasing loading of metal oxides with a nonuniform distribution of the metal oxide species in the pores.

For further insight on the structural details of the films, a series of TEM and SEM images together with EDS data have also been collected and analyzed from a group of samples. Panels (a) and (b) of Figure 4 are the SEM images of the meso-SiO ${ }_{2}-\mathrm{ZnO}-1.14$ sample. The images show sponge-like disordered mesostructures. The EDS data collected from various parts of the films using $\mathrm{Si}, \mathrm{O}$, and $\mathrm{Zn}$ (or $\mathrm{Cd}$ ) lines shows similar elemental composition, indicating homogeneous distribution of the silica and metal oxide domains in the films. Panels $(\mathrm{c}-\mathrm{e})$ of Figure 4 display TEM images of the meso- $\mathrm{SiO}_{2}-\mathrm{ZnO}-0.86$, meso$\mathrm{SiO}_{2}-\mathrm{ZnO}-1.14$, and meso-SiO $2-\mathrm{ZnO}-0.57$ samples, respectively. The TEM images show sponge-like disordered features in all samples. The thickness of the features is on average 1.4-1.6 nm (Figure 4e). The TEM images show that the darker domains are nanocrystalline; the lattice fringes can be clearly observed. The contrast analysis along the yellow line, shown in the inset of Figure 4e, clearly shows that the lattice fringes are $0.281 \mathrm{~nm}$ apart, originating from the (100) planes of wurtzite $\mathrm{ZnO}$ nanocrystallites. Furthermore, the fast Fourier transform (FFT) of a selected area of the image gives lattice spots located at $3.55,3.85$, and $6.15 \mathrm{~nm}^{-1}$, corresponding to lattice spacing of $0.281,0.260$, and $0.162 \mathrm{~nm}$, originating from the (100), (002), and (110) lattice planes of the $\mathrm{ZnO}$ nanocrystallites (Figure 4f). Note also that the calculated unit cell parameters (about $a=$ 0.325 and $c=0.520 \mathrm{~nm}$ ) are consistent with the unit cell parameters of wurtzite $\mathrm{ZnO} .^{35}$ Figure 5 shows a series of TEM images obtained from the meso- $\mathrm{SiO}_{2}-\mathrm{CdO}-n$ samples, where $n$ is $0.57,0.86$, and 1.14. Panel (a) of Figure 5 shows sponge-like mesoporous small domains. Panels $(b-d)$ of Figure 5 show that the pore walls are nanocrystalline $\mathrm{CdO}$ in all compositions. 

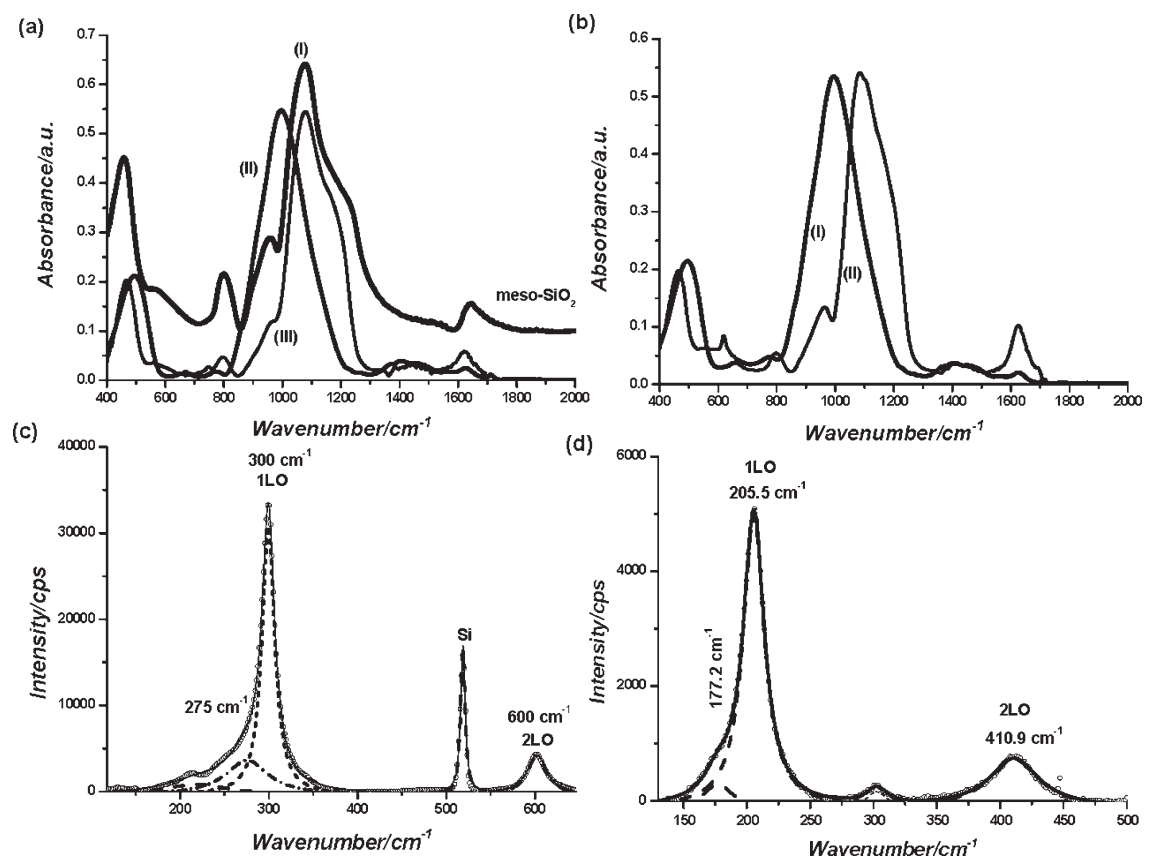

Figure 8. FTIR spectra of (a) (I) pure meso-SiO 2 and before (II) and after $\mathrm{H}_{2}$ Se reaction of meso- $\mathrm{SiO}_{2}-\mathrm{CdO}-0.86$, (b) before (I) and after (II) $\mathrm{H}_{2} \mathrm{~S}$ reaction of meso-SiO $2-\mathrm{CdO}-0.86$. The Raman spectra of (c) meso-SiO${ }_{2}-\mathrm{CdS}-0.86$ and (d) meso-SiO${ }_{2}-\mathrm{CdSe}-0.86$ thin films.

Clearly, the darker contrast in the images guides the disordered mesopores as discussed in the $\mathrm{N}_{2}$ sorption section. The FFT and its inverse FFT of the selected region in the TEM image display lattice spots and fringes in the darker regions of the images. Careful analysis of the TEM images identifies lattice fringes, spaced by $0.332,0.271$, and $0.235 \mathrm{~nm}$, originating from the $\mathrm{NaCl}$ structure of nanocrystalline $\mathrm{CdO}$. These lattice fringes correspond to (110), (111), and (200) planes, respectively, of the cubic $\mathrm{CdO}$ lattice with a unit cell constant of $0.469 \mathrm{~nm}^{36}$

The UV-vis absorption spectra of both meso-SiO $\mathrm{S}_{2}-\mathrm{ZnO}-n$ and meso-SiO $\mathrm{S}_{2}-\mathrm{CdO}-n$ samples were also recorded using the film samples coated over quartz slides (Figure S3a of the Supporting Information and Figure 6). Notice that the absorption intensity and absorption edge in the UV region gradually increase and red shift with the increasing $\mathrm{ZnO}$ content of the film samples (Figures S3a of the Supporting Information and Figure 6a). A similar trend is observed from the meso- $\mathrm{SiO}_{2}-\mathrm{CdO}-n$ samples (Figure $6 \mathrm{~b})$. The blue shift from the bulk band gap $(3.37 \mathrm{eV})^{37}$ is 2.48 and $1.52 \mathrm{eV}$ for the meso- $\mathrm{SiO}_{2}-\mathrm{ZnO}-0.29$ and meso$\mathrm{SiO}_{2}-\mathrm{ZnO}-1.14$, respectively; all other compositions are between these two band gap values, which follow an exponential decay (Figure S3b of the Supporting Information). The large blue shift is an indication of the existence of extremely small nanoparticles or a few layers of zinc oxide over the silica framework. The blue shift is due to the quantum confinement effect and corresponds to a thickness or particle size of around 1.4 to $1.7 \mathrm{~nm}$, calculated using effective-mass mode ${ }^{38}$ (Figure S3b of the Supporting Information). The absorption edge of the meso$\mathrm{SiO}_{2}-\mathrm{CdO}-n$ film samples also follows a similar trend, where the shift from the bulk $\mathrm{CdO}$ is even larger (Figure $6 \mathrm{~b}$ ). The shift from the bulk $\mathrm{CdO}$ is $2.84 \mathrm{eV}$ in the meso- $\mathrm{SiO}_{2}-\mathrm{CdO}-1.14$ corresponds to a film thickness of $1.6 \mathrm{~nm}$ (Figure S3b of the Supporting Information for the other compositions). The thickness or the particle size calculated from the absorption edge is consistent with the particle size/thickness determined from the TEM images.
Combining the results of FTIR and UV-vis absorption spectroscopy, $\mathrm{N}_{2}$ sorption data, and TEM images shows that the silanol groups of the silica framework react with the metal ions to form $\mathrm{Si}-\mathrm{O}-\mathrm{M}$ bonds at the silica - metal oxide interface on the pore walls, where the metal oxides are grown from those sides. The surface coverage, listed in Table 1, was calculated using the BET, UV-vis, and TEM data (details are given in the table footnotes). Complete coverage of the silica surface was achieved at around $0.86 \mathrm{Cd}(\mathrm{II})$ per silicon in the meso-SiO${ }_{2}-\mathrm{CdO}-n$ sample, but even at $1.14 \mathrm{Zn}$ (II) per silicon, the surface coverage in the meso- $\mathrm{SiO}_{2}-\mathrm{ZnO}-n$ sample is about $50 \%$ (Table 1). Notice that the $\mathrm{Si}-\mathrm{O}-\mathrm{M}$ stretching mode around the $850-1000 \mathrm{~cm}^{-1}$ region gradually increases with increasing metal ion concentration of the samples up to a $1.14 \mathrm{Zn}$ (II) to silicon ratio (Figure 2a and Figure S4 of the Supporting Information), clearly showing the surface coverage continues up to a $1.14 \mathrm{Zn}$ (II) to silica mole ratio. Furthermore, the particle size that was determined using the TEM images and UV-vis absorption edge (from the band gap using effective mass model) is very similar in all compositions. The absorption edge gradually increases but not at the same rate as the metal to silicon mole ratio. The spectral changes (gradual increase in the $\mathrm{Si}-\mathrm{O}-\mathrm{M}$ stretching mode and shallow increase in the absorption edge) and similar particle size in the TEM images, with an increasing metal oxide concentration in the meso- $\mathrm{SiO}_{2}-\mathrm{MO}-n$ thin films eliminate the possibility of first full monolayer coverage on the silica wall surface and then growth of the nanocrystalline metal oxides over the silica walls. ${ }^{27}$ It is likely that the metal oxides on the pore surface of the mesoporous silica form thin metal oxide nano-islands. These islands grow and cover the surface of the mesoporous silica in the $\mathrm{CdO}$ case.

To further prove our hypothesis, the silica walls of the meso$\mathrm{SiO}_{2}-\mathrm{CdO}-0.86$ film were gently etched using a $4 \%$ aqueous $\mathrm{HF}$ solution. Figure 7 shows TEM images, an FFT of a large TEM image, and a SAED pattern. The TEM images show plate-like features with lattice fringes corresponding to crystalline $\mathrm{CdO}$ 

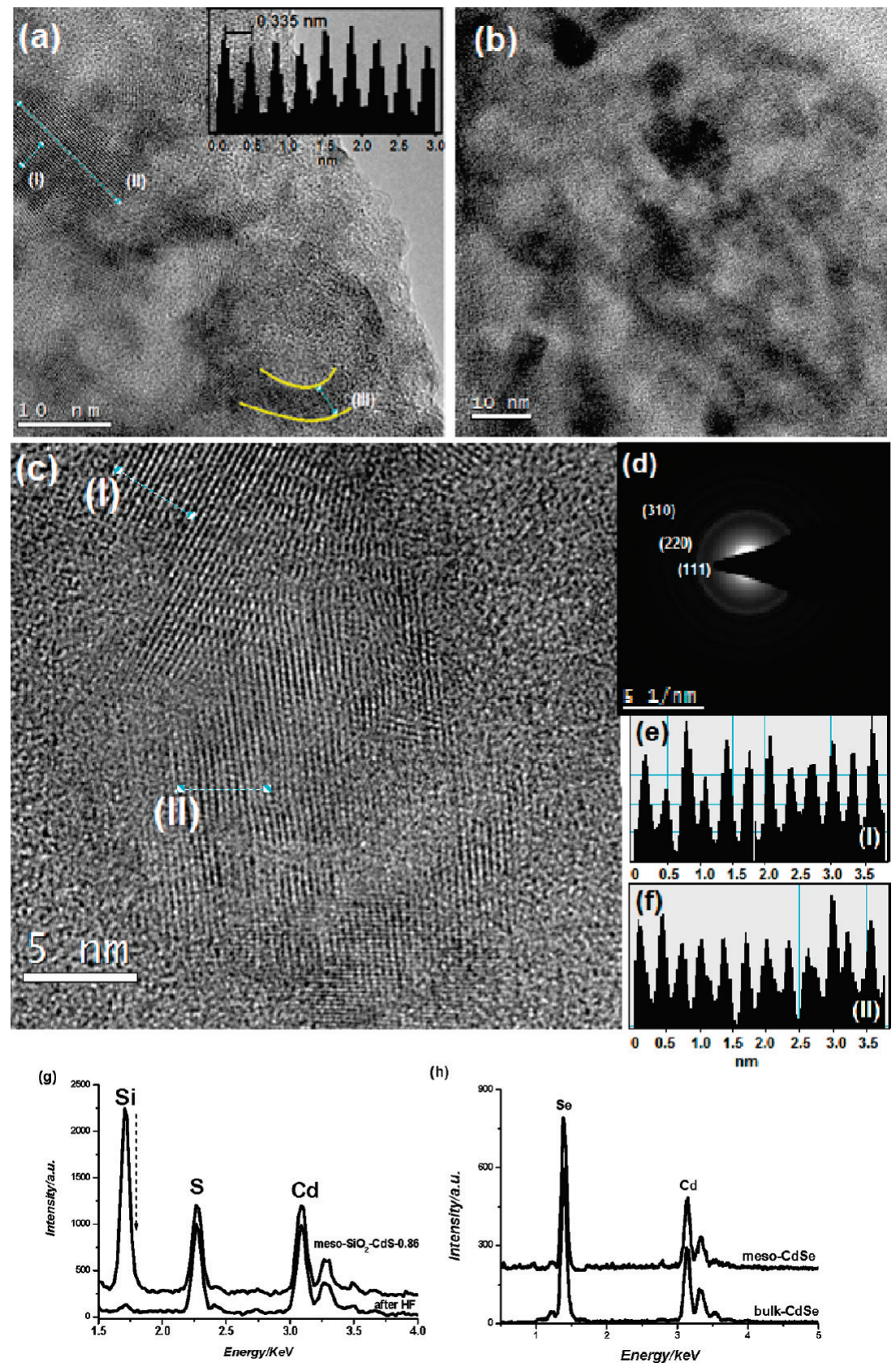

Figure 9. TEM images of (a) meso- $\mathrm{SiO}_{2}-\mathrm{CdS}-0.86$ (inset, histogram along line (I)) and (b) meso-SiO ${ }_{2}-\mathrm{CdSe}-0.86$. TEM image (c), SAED (d), and (e, f) histograms along the lines (I) and (II) in panel (c) of the meso-SiO ${ }_{2}-\mathrm{CdS}-0.86$ after HF etching. EDS data of $m e s o-S i O_{2}-\mathrm{CdS}-0.86$ before and after $\mathrm{HF}$ treatment $(\mathrm{g})$ and bulk $\mathrm{CdSe}$ and $m e s o-\mathrm{SiO}_{2}-\mathrm{CdSe}-0.86$ after HF treatment $(\mathrm{h})$.

nano-islands (Figure 7a,d). Notice that these particles are as large as $10-15 \mathrm{~nm}$ with a likely thickness of around $1.6 \mathrm{~nm}$ as determined from their UV-vis absorption spectra. Note also that the absorption edge does not change upon etching. The FFT of a large area TEM image shows two rings, originating from the (200) and (220) planes of crystalline CdO. The SAED pattern also displays diffraction rings from the (200) and (220) planes and weaker rings from higher-order planes corresponding to a face-centered cubic CdO (Figure 7c). These observations clearly ensure that the metal oxides are growing over the silica walls and eliminate the possibility of mixed oxide formation during the annealing stage of the preparation.
The presence of $\mathrm{CdO}$ nano-islands in the meso- $\mathrm{SiO}_{2}-\mathrm{CdO}-n$ films were further confirmed by reacting the samples under $\mathrm{H}_{2} \mathrm{~S}$ or $\mathrm{H}_{2} \mathrm{Se}$ atmospheres at room temperature to convert $\mathrm{CdO}$ nano-islands into $\mathrm{CdS}$ or CdSe nano-islands, respectively. The $\mathrm{H}_{2} \mathrm{~S}$ reaction proceeds until all $\mathrm{Si}-\mathrm{O}-\mathrm{Cd}$ bonds break, as monitored using FTIR spectroscopy (Figure 8a,b). The meso$\mathrm{SiO}_{2}-\mathrm{CdO}-n$ samples display a peak and a shoulder at 914 and $864 \mathrm{~cm}^{-1}$, respectively, due to the $\mathrm{O}_{3} \mathrm{Si}-\mathrm{O}-\mathrm{Cd}(\mathrm{O})_{6}$ interface species; the $\mathrm{CdO}$ are nanocrystalline on the silica surface with cubic ( 6 coordinated) structures. The peaks due to the $\mathrm{Si}-\mathrm{O}-\mathrm{M}$ bonds disappear and the peaks, due to the pure silica, appear upon completion of the $\mathrm{H}_{2} \mathrm{Se}$ or $\mathrm{H}_{2} \mathrm{~S}$ reactions (Figure 8a,b). The spectra of all the samples after complete $\mathrm{H}_{2} \mathrm{~S}$ and $\mathrm{H}_{2} \mathrm{Se}$ 
reactions closely resemble the spectrum of the pure silica. The Raman spectra of the meso-SiO${ }_{2}-\mathrm{CdS}-n$ and $m e s o-\mathrm{SiO}_{2}-\mathrm{CdSe}$ $n$ films show resonance Raman effects and display intense peaks due to longitudinal optical (LO) modes at 298 and $205 \mathrm{~cm}^{-1}$, respectively, with shoulders on their low energy side due to surface modes $^{39}$ (Figure 8c,d). The EDS data show a linear increase in the $\mathrm{Zn} / \mathrm{Si}$ and $\mathrm{Cd} / \mathrm{Si}$ intensity ratios with an increasing $n$ in the samples (meso-SiO ${ }_{2}-\mathrm{CdS}-n$ (or CdSe- $n$ ), where $n$ is $0.29,057,0.86$, and 1.14), indicating the homogeneity in the samples. The complete conversion of the cadmium oxide to cadmium sulfide or to cadmium selenide was also ensured using the EDS data; note that the $\mathrm{S} / \mathrm{Cd}$ and $\mathrm{Se} / \mathrm{Cd}$ intensity ratios are the same as their bulk counter parts upon completion of the corresponding reactions.

To further investigate the structural details of the films upon $\mathrm{H}_{2} \mathrm{~S}$ or $\mathrm{H}_{2} \mathrm{Se}$ reactions, we also recorded the TEM images of a series of samples (Figure 9). Panel (a) of Figure 9 is a TEM image obtained from the meso- $\mathrm{SiO}_{2}-\mathrm{CdS}-0.86$ film. The image shows lattice fringes from the crystalline $\mathrm{CdS}$ domains. A histogram of the line (I) is shown in the right corner of the image in panel (a) of Figure 9, where the distance between the lattice fringes is $0.335 \mathrm{~nm}$ and corresponds to the (111) planes of the zinc blende CdS nanocrystallites. ${ }^{40}$ Notice also that there are $15 \mathrm{~nm}$ (line II) and $3.0 \mathrm{~nm}$ (line III and yellow partial circle) crystalline domains (Figure 9a). The crystalline domains likely originate from the nano-islands along the pore axis and thickness axis as predicted from the band gap values, respectively, observed all over the samples. Note also that if the particles are as large as $15 \mathrm{~nm}$, one should not observe any blue shift from their bulk counter parts in the UV-vis absorption spectra. Therefore, there must be at least a quantum confinement along one of the axes (thickness axis of the nano-islands). The TEM image panel (b) of Figure 9 obtained from the meso- $\mathrm{SiO}_{2}-\mathrm{CdSe}-0.86$ predominantly displays features originating from the wall axis (thickness axis) of the CdSe nanocrystallites and correlates our hypothesis.

The meso- $\mathrm{SiO}_{2}-\mathrm{CdS}-0.86$ and meso-SiO$-\mathrm{CdSe}$ films were etched using a $4.0 \%$ aqueous HF. Complete etching of the silica domains takes only a few second in a dilute HF solution, where the samples after etching are denoted as meso-CdS and mesoCdSe. The TEM image in panel (c) of Figure 9 displays two large nanoflakes of CdS as lattice fringes in each plate aligned in different directions, marked as (I) and (II). The nanoflakes are 10 to $25 \mathrm{~nm}$ wide and likely originated from the nano-islands over the porewall (Figure 9c). The lattice fringes along the lines (I) and (II) are spaced by $0.335 \mathrm{~nm}$, corresponding to the (111) planes of the CdS lattice (Figure 9c,e,f). The SAED patterns are also identical before and after the HF treatment, indicating that the CdS particles are as dispersed and random as before the HF treatment (Figure 9d). Each ring from inside to out corresponds to the (111), (220), and (311) planes of the zinc blende CdS. The details of the $\mathrm{H}_{2} \mathrm{~S}$ and $\mathrm{H}_{2}$ Se reactions and further characterization of these samples will be presented elsewhere.

\section{CONCLUSION}

The salt-surfactant LLC mesophase concept and the EISA method have been successfully employed to encapsulate up to a 1.14 salt $(\mathrm{ZnX}$ or $\mathrm{CdY})$ per silica mole ratio in the mesostructured silica films. We took advantage of the salt-surfactant system, in which the primary solvent is the salt in its molten phase. Notice that this solvent does not evaporate during the assembly and calcination process to design mesoporous silica - metal oxide thin films. This property of the salt-surfactant LLC mesophase system clearly distinguishes from the EISA process. We found that two parameters are critically important in this assembly process: one is the amount of charge surfactant (CTAB) that compensates the surface charges of the molten salt domains, confined between the silica walls and surfactant domains in the mesostructured thin films, and the other is the effect of confined space that depresses the freezing point of the salt used. The calcined film samples contain uniformly coated 1.4-1.7 $\mathrm{nm}$ thick crystalline metal oxide nano-islands on the pore walls of mesoporous silica films. Using this approach, the metal oxide on the pore walls can be adjusted up to 61 and $71 \mathrm{w} / \mathrm{w} \%$ in the meso- $\mathrm{SiO}_{2}-\mathrm{ZnO}-n$ and meso- $\mathrm{SiO}_{2}-\mathrm{CdO}-n$ samples, respectively. An $\sim 100 \%$ and $\sim 50 \%$ surface coverage can be achieved in the meso- $\mathrm{SiO}_{2}-\mathrm{CdO}-n$ and meso- $\mathrm{SiO}_{2}-\mathrm{ZnO}-n$ thin films using the method developed in this work. The nanocrystallites form as nano-islands and spatially grow to cover the silica surface. Finally, the metal oxide nano-islands can be recovered by etching out the silica layers. The method is not limited to $\mathrm{ZnO}$ and $\mathrm{CdO}$; it can be employed for other salts and metal oxides, mixed metal oxides, metal sulfides, and metal selenides, etc.

\section{ASSOCIATED CONTENT}

(5) Supporting Information. Wide-angle XRD patterns, FTIR spectra of all the fresh coated films, temperature-dependent FTIR spectra, UV-vis absorption spectra of meso-SiO ${ }_{2}-$ $\mathrm{ZnO}-n$ films, plot of thickness of the oxide nano-islands versus composition, and convoluted FTIR spectra of the $\mathrm{Si}-\mathrm{O}-\mathrm{M}$ stretching region of meso-SiO ${ }_{2}-\mathrm{ZnO}-n$ films (PDF). This material is available free of charge via the Internet at http:// pubs.acs.org.

\section{AUTHOR INFORMATION}

\section{Corresponding Author}

*E-mail: dag@fen.bilkent.edu.tr. Fax: (90) 3122664068.

\section{ACKNOWLEDGMENT}

We thank Mustafa Güler for TEM and Dr. Neil Coombs for the SEM measurements. We also thank TUBITAK (110T813), Turkish Academy of Science, and UNAM-Regpot (Contract 203953) for partial financial support.

\section{REFERENCES}

(1) Attard, G. S.; Glyde, J. C.; Göltner, C. G. Nature 1995, 378, 366-368.

(2) Brinker, C. J.; Lu, Y.; Sellinger, A.; Fan, H. Adv. Mater. 1999, $11,579-585$.

(3) Brezesinski, T.; Groenewolt, M.; Gibaud, A.; Pinna, N.; Antonietti, M.; Smarsly, B. M. Adv. Mater. 2006, 18, 2260-2263.

(4) Grosso1, D.; Boissière1, C.; Smarsly, B.; Brezesinski, T.; Pinna, N.; Albouy, P. A.; Amenitsch, H.; Antonietti, M.; Sanchez, C. Nat. Mater. 2004, 3, 787-792.

(5) Crepaldi, E. L.; Soler-Illia, G. J. A. A.; Grosso, D.; Cagnol, F.; Ribot, F.; Sanchez, C. J. Am. Chem. Soc. 2003, 125, 9770-9786.

(6) Hatton, B. D.; Landskron, K.; Whitnall, W.; Perovic, D. D.; Ozin, G. A. Adv. Mater. 2005, 15, 823-829.

(7) Choi, S. Y.; Mamak, M.; Coombs, N.; Chopra, N.; Ozin, G. A. Adv. Funct. Mater. 2004, 14, 335-344.

(8) Yamauchi, Y.; Ohsuna, T.; Kuroda, K. Chem. Mater. 2007, $19,1335-1342$. 
(9) Zhang, W. H.; Shi, J. L.; Wang, L. Z.; Yan, D. S. Chem. Mater. 2000, 12, 1408-1413.

(10) Sauer, J.; Marlow, F.; Schüth, F. Phys. Chem. Chem. Phys. 2001, 5579-5584.

(11) Sauer, J.; Marlow, Spliethoff, B.; F.; Schüth, F. Chem. Mater. 2002, 14, 217-224.

(12) Polarz, S.; Orlov, A. V.; Schüth, F.; Lu, A.-H. Chem. Eur. J. 2007, 13, 592-597.

(13) Lepoutre, S.; Lopez, B. J-.; Sanchez, C.; Amenitsch, H.; Linden, M.; Grosso, D. J. Mater. Chem. 2010, 20, 537-542.

(14) Bauvy, C.; Chelnokov, E.; Marine, W.; Sporken, R.; Su, B. L. J. Non-Cryst. Solids 2009, 355, 1152-1156.

(15) Coasne, B.; Mezy, A.; Pellenq, R. J. M.; Ravot, D.; Tedenac, J. C. J. Am. Chem. Soc. 2009, 131, 2185-2198.

(16) Tura, C.; Coombs, N.; Dag, Ö. Chem. Mater. 2005, 17, 573-579.

(17) Akdogan, Y.; Üzüm, Ç.; Dag, Ö.; Coombs, N. J. Mater. Chem. 2006, 16, 2048-2055.

(18) Okur, H. İ.; Türker, Y.; Dag, Ö. Langmuir 2010, 26, 538-544.

(19) Wang, Y.; Wu, Z.; Shi, L.; Zhu, J. Adv. Mater. 2005, $17,323-327$.

(20) Wang, Y.; Wu, Z.; Wang, H.; Zhu, J. Adv. Funct. Mater. 2006, $16,2374-2386$.

(21) Wu, Z. Y.; Jiang, Q.; Wang, Y. M.; Wang, H. J.; Sun, L. B.; Shi, L. Y.; Xu, J. H.; Wang, Y.; Chun, Y.; Zhu, J. H. Chem. Mater. 2006, $18,4600-4608$.

(22) Jiang, Q.; Wu, Z. Y.; Wang, Y. M.; Cao, Y.; Zhou, C. F.; Zhu, J. H. J. Mater. Chem. 2006, 16, 1536-1542.

(23) Li, E.; Rudolph, V. Energy Fuels 2008, 22, 145-149.

(24) Tian, W.-H.; Sun, L.-B.; Song, X.-L.; Liu, X.-Q.; Yin, Y.; He, G.-S. Langmuir 2010, 26, 17398-17404.

(25) Albayrak, C.; Soylu, A. M.; Dag, Ö. Langmuir 2008, 24, 10592-19595.

(26) Albayrak, C.; Soylu, A. M.; Dag, Ö. J. Colloid Interface Sci. 2010, 341, 109-116.

(27) Albayrak, C.; Özkan, N.; Dag, Ö. Langmuir 2011, 27, 870-873.

(28) Vargas-Florencia, D.; Petrov, O.; Furó, I. J. Phys. Chem. B 2006, $110,3867-3870$.

(29) Çelik, Ö.; Dag, Ö. Angew. Chem., Int. Ed. 2001, 40, 3800-3803.

(30) Dag, Ö.; Alayoğlu, S.; Uysal, I. J. Phys. Chem. B 2004, 108, 8439-8446.

(31) Demirörs, A. F.; Eser, B. E.; Dag, Ö. Langmuir 2005, 21, 4156-4162.

(32) Albayrak, C.; Gülçin, G.; Dag, Ö. Langmuir 2007, 23, 855-860.

(33) Gao, X.; Bare, S. R.; Fierro, J. L. G.; Banares, M. A.; Wachs, I. E. J. Phys. Chem. B 1998, 102, 5653-5666.

(34) Alba, M. D.; Luan, Z.; Klinowski, J. J. Phys. Chem. 1996, 100, 2178-2182.

(35) Ashrafi, A.; Jagadish, C. J. Appl. Phys. 2007, 102 (071101), $01-12$.

(36) Zhang., R. J. Phys. Chem. Minerals 1999, 26, 644-648.

(37) Özgür, Ü.; Alivov, Y. I.; Liu, C.; Teke, A.; Reshchikov, M. A.; Doğan, S.; Avrutin, V.; Cho, S. J.; Morkoç, H. J. Appl. Phys. 2005, 98, 041301.

(38) Brus, L. J. Phys. Chem. 1986, 90, 2555-2560.

(39) Dinger, A.; Göppert, M.; Becker, R.; Grün, M.; Petillon, S.; Klingshirn, C.; Liang, J.; Wagner, V.; Geurts J. Phys. Rev. B 2001, 64, 245310.

(40) Zakharov, O.; Rubio, A.; Blasé, X.; Cohen, M. L.; Louie, S. G. Phys. Rev. B 1994, 50, 10780-10787. 